\title{
ANALISIS PENDAPATAN PAJAK DAN RETRIBUSI TERHADAP BELANJA MODAL DAM DAMPAKNYA PADA PERTUMBUHAN EKONOMI KOTA MANADO 2007-2015
}

\author{
Nofianti. L Halim ${ }^{1}$, Anderson G. Kumenaung ${ }^{2}$, Daisy S,M Engka ${ }^{3}$ \\ Fakultas Ekonomi dan Bisnis, Magister Ilmu Ekonomi \\ Universitas Sam Ratulangi, Manado
}

\begin{abstract}
ABSTRAK
Alokasi belanja pemerintah sangat erat kaitannya dengan pembangunan yang terjadi di pusat maupun di daerah salah satunya adalah pembangunan dalam bidang ekonomi, tentu selain baik alokasi anggaran yang dikeluarkan pemerintah melalui belanja langsung dan belanja tidak langsung untuk pembangunan sector ekonomi maka akan semakin baik pula peningkatan atau pertumbuhan yang terjadi pada sector ekonomi tersebut yang secara agregat akan meningkatkan pertumbuhan ekonomi.

Dalam penelitian ini digunakan analisis regresi berganda untuk melihat seberap besar pengaruh belanja langsung dan belanja tidak mempengaruhi peningkatan sector keuangan, real estate dan jasa keuangan. Dan dari hasil penghitungan matematika didapatkan hasil bahwa belanja langsung tidak mempunyai korelasi positif dan signifikan terhadap peningkatan sector yang diteliti, begitu pun dengan alokasi belanja tidak langsung mempunyai korelasi positif namun tingkat signifikansinya masih kurang apabila dilihat secara parsial. Namun pada saat dilakukan penghitungan $R$ square didapatkan angka positif tingkat keterpengaruhan dua variable independent atau variable belanja belanja langsung dan tidak langsung terhadap variable dependent pertumbuhan ekonomi.
\end{abstract}

Kata kunci: Pajak, retribusi belanja modal, pertumbuhan ekonomi

\section{ABSTRACT}

The allocation of government spending is closely associated with the development that occurs in the central and local levels one of which is the development in the field of economics, of course in addition to better budget allocation by the government through direct expenditures and indirect expenditures for the construction sector of the economy, the better the increase or growth that occurred in the economic sector which in aggregate would increase economic growth.

In this study used multiple regression analysis to see the influence seberap direct expenditure and expenditure does not affect the increase in the financial sector, real estate and financial services. And the results of mathematical calculations showed that direct spending does not have a positive and significant correlation to increased sectors studied, as was the allocation of indirect expenditure has positive correlation but still less than the level of significance when seen partially. However, at the time of calculation of figures obtained $R$ square positively influence level two independent variables or variable direct expenditure and indirect expenditure the dependent variable economic growth.

Keywords: tax, levies, capital expenditure, economic growth

\section{PENDAHULUAN}

\section{Latar Belakang}

Meningkatnya perekonomian suatu daerah Meruapakan gambaran pengelolaan keuangan yang efisien dengan memaksimalkan berbagai sektor perekonomian yang dimiliki. Sektor-sektor perekonomian yang terkelola dengan maksimal dan serasi tentu akan memberi efek agregat terhadap peningkatan perekonomian. Pembangunan daerah dengan memaksimalkan potensi-potensi yang dimiliki tentu akan berimbas pada peningkatan pendapatn sebuah daerah yang nantinya akan memberi kemampuan kepada sebuah daerah untuk semakin mandiri dalam sektor pendapatan yang tentunya akan mensejahterakan masyarakat daeraah tersebut, melalui peningkatan pembangunan serta ketersediaan dana yang mencukupi dalam tatanan keuangan daerah untuk terus menggenjot perekonomian.

Sebuah pembangunanan ekonomi adalah proses dimana pemerintah masyarakat serta pihak terkait mengelola dan memanfaatkan sumber daya yang secara maksimal serta membentuk lapangan kerja baru 
guna memaksimalkan potensi pertumbuhan ekonomi di dalam wilayah tersebut. Dewasa ini di berbagai daerah masih belum bisa menggelola dengan maksimal sektor-sektor perekonomian yang dimiliki dan masih tingginya tingkat ketergantungan terhadap dana dari pemerintah pusat. Pendapatan Asli Daerah (PAD) yang masih tergolong rendah membuat pemerintah daerah belum bisa meningkatkan kemandiriannya yang berimbas pada pembangunan yang dilakukan di daerah yang bersangkutan sehingga masih tingginya tingkat kemiskinan yang dimiliki di daerah, karena kurangnya kesempatan kerja dan sedikit investor yang ingin menanamkan modalnya di sebuah daerah yang belum bisa menyediakan sarana dan prasarana investasi yang memadai. Akibatnya pemerintah pusat harus rela menanggung beban pengeluaran sebuah daerah dengan kucuran Dana Transfer untuk meningkatkan Anggaran Pendapatan dan Belanja Daerah (APBD). UndangUndang No 33 Tahun 2004 tentang perimbangan keuangan antara pemerintah pusat dan daerah telah digulirkan pada 1 Januari 2001. Adanya Undang-Undang tersebut telah mengakibatkan pergeseran paradigma penyelenggaraan pemerintah dari paradigma sentralistis ke arah desentralisasi yang ditandai dengan pemberian otonomi yang luas dan nyata kepada daerah. Hal ini tentu menjadi jalan bagi pemerintah daerah untuk lebih maksimal dalam memanfaatkan dan mengelola sumber-sumber ekonomi yang dimilikinya, meskipun tidak sedikit masalah yang dihadapi dalam pelaksanaannya oleh karena itu, pemerintah mengeluarkan Undang-Undang No.32 Tahun 2004 tentang pemerintahan daerah dan UndangUndang No.33 Tahun 2004 tentang perimbangan keuangan antara pemerintah pusat dan pemerintah daerah. Pengalihan pembiayaan dari pusat ke daerah atau yang lebih dikenal sebagai desentralisasi fiscal, dapat pula diartikan sebagai suatu proses distribusi anggaran dari pemerintah yang lebih tinggi kepada pemerintah yang lebih rendah untuk kemudian dikelola guna mendukung fungsi atau tugas pemerintahan dan pelayanan public sesuai dengan banyaknya wewenang bidang pemerintahan yang diberikan atau dilimpahkan oleh pemerintah pusat (Saragih 2003: 82).

Dalam hubungannya, antara pemerintah pusat dan daerah menyangkut desentralisasi fiscal, dana perimbangan merupakan salah satu komponen utama yang mempengaruhi tingkat kemampuan daerah tersebut dalam mecukupi kebutuhan anggaran belanjanya di setiap periode. Perimbangan keuangan merupakan salah satu bentuk hubungan antara pemerintah pusat dan daerah dari sekian banyak hubungan yang dimilikinya, hubungan ini sendiri bersifat (intergovernmental fiscal relation system), sebagai salah satu bentuk kerjasama dalam pendelegasian wewenang pemerintah. Dalam kenyataannya sendiri prosentase kemampuan daerah dalam membiayai pengeluarannya masih kecil dan sebagian besar masih berharap pada dana transfer dari pemerintah pusat. Sebagian besar wilayah Indonesia masih sangat kecil yakni masih berada di kisaran 25\% dari Total Penerimaan Daerah (TPD), hal ini menunjukan bahwa pendapatan daerah guna menyokong anggaran belanjanya masih dditopang sebagian besarnya oleh dana transfer pemerintah pusat dan sumbangan-sumbangan lainnya yang sah dan telah diatur di dalam undang-undang yakni sebesar 75\% persen dari Total Pendapatan Daerah (TPD).

Hal ini tentu mengindikasikan bahwa kemampuan daerah untuk dapat mengatur perekonomian serta potensi yang dimilikinya masih sangat terbatas karena factor ketergantungan kepada pemerintah pusat yang masih amat besar, sehingga banyak kebijakan dari pemerintah pusat dalam pengelolaan potensi sumber keuangan harus diikuti oleh pemerintah daerah, dan sumber-sumber keuangan yang potensial masih tetap dikuasai oleh pemerintah pusat (Yani, 2002:3). Sulawesi Utara adalah daerah yang berada di ujung utara pulau sulawesi dan berada di kawasan timur Indonesia merupakan salah satu daerah yang tengah menjadi sorotan baik di Indonesia bahkan dunia. Perputaran ekonomi yang cepat serta banyaknya peluang investasi yang kian terbuka menyebabkan perekonomian ikut terpacu. Letak geografis di bibir pasifik menjadikannya daerah yang berpotensi menjadi pusat perdagangan bukan hanya kawasan Indonesia Timur namun juga pusat perdagangan dunia. Saat ini berbagai sumber perekonomian potensial terus digalakan pemerintah untuk merangsang investor dan pemodal baik dari sektor swasta dan pemerintah, dalam maupun luar negeri untuk menanamkam modalnya di bumi nyiur melambai. Hal ini tentu bertujuan bukan hanya demi keuntungan sesaat namun guna menunjang peningkatan perekonomian serta membuka akses global melalui komunitas masyarakat asean dengan Kota Manado sebagai ibukotanya. Pasca otonomi daerah Manado sebagai Ibukota Propini Sulawesi Utara dan juga sebagai pintu masuk perdagangan terus menikmati perkembangan pertumbuhan ekonomi yang signifikan dari tahun ke tahun bahkan jika dibandingkan dengan daerah lainnya di Sulawesi Utara, Manado menempati peringkat teratas. Dengan semakin berkembangnya akses ke Kota Manado tentu membuka pintu selebar-lebarnya bagi investor untuk masuk dan menanamkan modalnya, 
sehingga dapat memberikan kontribusi bagi pertumbuhan ekonomi kota Manado dengan membuka lapangan kerja serta peluang usaha bagi masyarakat luas.

Dengan adanya sumber-sumber PAD yang baru maka diharapkan kedepannya akan mampu mengurangi ketergantungan fiskal dari Pemerintah Pusat guna membiayai APBD nya sendiri, apalagi dilihat secara makro kemampuan perekonomian Kota Manado masih amat bergantung pada tingkat pertumbuhan nasional serta besarnya alokasi dana perimbangan dari pemerintah pusat. Didasari oleh kesadaran inilah, perhatian besar dan sungguh-sungguh dari Pemerintah Daerah Provinsi dan Pemerintah Daerah Kabupaten/kota untuk dapat meningkatkan faktor kemampuan daerah dalam membiayai APBDnya sendiri perlu untuk ditingkatkan guna mengurangi proporsi dana transfer pemerintah pusat dalam Total Penerimaan Daerah (TPD), yang merupakan salah satu tolak ukur tingkat kemandirian suatu daerah.

\section{Rumusan Masalah}

Tujuan utama dari pelaksanaan Otonomi adalah untuk membagi tanggung antara pemerintah pusat dan daerah yang bersangkutan, agar jalannya pemerintahan serta pelayanan masyarakat yang lebih terfokus karena pemerintah di daerah tentu lebih mengetahui permasalahan serta kebutuhan di daerah yang bersangkutan. Selain itu kemampuan sebuah daerah untuk mengelola serta memanfaatkan anggaran rumah tangganya sendiri sehingga bisa mencapai tahap yang maksimal dan dengan tujuan mensejahterakan masyarakat di daerah.

Hal ini tentu menarik untuk diteliti untuk melihat seberapa besar kontribusi pendapatan asli daerah (PAD) terhadap sektor pembiayaan pembangunannya. Berdasarkan latar belakang yang ada maka rumusan masalah yang akan dibahas adalah : Bagaimana Pendapatan Pajak, Retribusi Berpengaruh Terhadap Belanja Modal dan dampaknya terhadap pertumbuhan ekonomi di Kota Manado ?

\section{Tujuan Penelitian}

Tujuan penelitian ini adalah untuk melihat seberapa besar pengaruh yang diberikan Pendapatan Asli Daerah terhadap pembangunan ekonomi di kota Manado.

\section{Manfaat Penelitian}

1. Sebagai bahan masukan bagi pemerintah Kota Manado untuk mengetahui perkembangan perekonomiannya, terlebih dari sektor Pendapatan Asli Daerah serta belanja pembangunannya.

2. Untuk digunakan pihak yang berkepentingan untuk menganalisa masalah - masalah yang berhubungan dengan Pengelolaan fiskal Kota Manado.

\section{TINJAUAN PUSTAKA \\ Pajak Daerah}

Kesit (2003) menyatakan bahwa pajak daerah merupakan iuran wajib yang dilakukan oleh orang pribadi atau badan tanpa imbalan langsung yang seimbang, yang dapat dipaksakan berdasarkan undang-undang yang berlaku, yang hasilnya digunakan untuk membiayai penyelenggaraan pemerintahan daerah dan pembangunan daerah. Mardiasmo (1992) yang dimaksud dengan pajak daerah adalah pajak yang dipungut daerah berdasarkan peraturan pajak yang ditetapkan oleh daerah untuk kepentingan pembiayaan rumah tangga pemerintah daerah tersebut.

Pajak daerah dalam hal ini ditetapkan oleh peraturan daerah. Untuk menerbitkan peraturan daerah peraturan daerah tentang pajak diharuskan memenuhi kriteria sebagai berikut :

1) Bersifat pajak dan bukan retribusi

2) Objek pajak terletak atau terdapat di wilayah daerah kabupaten

3) Objek dan dasar pengenaan pajak tidak bertentangan dengan kepentingan umum

4) Objek pajak bukan objek provinsi dan atau objek pajak pusat.

5) Potensinya memadai, berarti bahwa hasil pajak cukup besar sebagai salah satu sumber pendapatan daerah dan laju pertumbuhannya diperkirakan sejalan dengan laju pertumbuhan ekonomi.

6) Tidak memberikan dampak ekonomi yang negatif, yang berarti bahwa pajak tidak mengganggu alokasi sumber-sumber ekonomi secara efisien dan tidak merintangi arus sumber daya ekonomi antar daerah dan kegiatan ekspor-impor (Halim dan Mujib, 2009). 
Pemerintah daerah harus memastikan bahwa penerimaan pajak lebih besar dari biaya pemungutannya. Selain itu, pemerintah daerah perlu menjaga stabilitas penerimaan pajak tersebut. Fluktuasi penerimaan pajak hendaknya dijaga tidak terlalu besar sebab jika sangat berfluktuasi juga kurang baik untuk perencanaan keuangan daerah (Mahmudi, 2010).

\section{Retribusi Daerah}

Menurut Sumitro (1979), pengertian retribusi secara umum adalah pembayaran-pembayaran kepada negara yang dilakukan oleh mereka yang menggunakan jasa-jasa negara. Pengertian yang hampir sama diberikan oleh Munawir (1980), retribusi daerah adalah iuran kepada pemerintah yang dapat dipaksakan dan jasa balik secara langsung dapat ditunjuk. Paksaan disini bersifat ekonomis karena siapa saja yang tidak merasakan jasa balik pemerintah dia tidak dikenakan iuran itu.

Retribusi daerah pada umumnya merupakan sumber pendapatan penyumbang PAD kedua setelah pajak daerah. Bahkan untuk beberapa daerah penerimaan retribusi daerah ini lebih tinggi daripada pajak daerah. Retribusi daerah memiliki karakteristik yang berbeda dengan pajak daerah. Pajak daerah merupakan pungutan yang dilakukan pemerintah daerah kepada wajib pajak atas pembayaran pajak tersebut. Sementara itu, retribusi daerah merupakan pungutan yang dilakukan pemerintah daerah kepada wajib retribusi atas pemanfaatan suatu jasa tertentu yang disediakan pemerintah. Jadi dalam hal ini terdapat imbalan langsung yang dapat dinikmati pembayar retribusi.

Terdapat tiga jenis retribusi daerah yaitu, retribusi jasa umum, retribusi jasa usaha, dan retribusi perizinan tertentu. Berbeda dengan pajak daerah yang bersifat tertutup, untuk retribusi ini pemerintah daerah masih diberi peluang untuk menambah jenisnya namun harus pula memenuhi persyaratan tertentu sebagaimana diatur undang-undang (Mahmudi, 2010)

Karena retribusi ini terkait dengan pelayanan tertentu, maka prinsip manajemen retribusi daerah yang paling utama adalah perbaikan pelayanan tersebut. Tentunya selain perbaikan pelayanan, pemerintah daerah juga perlu melakukan berbagai perbaikan sebagaimana halnya pajak daerah, seperti perluasan basis retribusi, pengendalian atas kebocoran penerimaan retribusi, dan perbaikan administrasi pemungutan retribusi (Mahmudi, 2009).

\section{Belanja Modal}

Menurut Peraturan Menteri Dalam Negeri Nomor 13 Tahun 2006 tentang Pedoman Pengelolaan Keuangan Daerah Pasal 53, belanja modal adalah anggaran pengeluaran APBD yang digunakan untuk pengeluaran yang dilakukan dalam rangka pembelian/ pengadaan atau pembangunan aset tetap berwujud yang mempunyai nilai manfaat lebih dari 12 (dua belas) bulan untuk digunakan dalam kegiatan pemerintahan, seperti dalam bentuk tanah, peralatan dan mesin, gedung dan bangunan, jalan, irigasi dan jaringan, dan asset tetap lainnya. Belanja modal menurut Peraturan Menteri Dalam Negeri Nomor 59 Tahun 2007 tentang Perubahan Atas Peraturan Menteri Dalam Negeri Nomor 13 Tahun 2006 tentang Pedoman Pengelolaan Keuangan Daerah Ketentuan Pasal 52, adalah belanja barang atau jasa yang dianggarkan pada pengeluaran APBD yang digunakan untuk menganggarkan pengadaan barang dan jasa yang nilai manfaatnya lebih dari 12 (dua belas) bulan dalam melaksanakan program dan kegiatan pemerintah daerah. Nilai asset tetap berwujud yang dianggarkan dalam belanja modal sebesar harga beli/ bangun aset ditambah seluruh belanja yang terkait dengan pengadaan/ pembangunan aset sampai aset tersebut siap digunakan (Rudy Badrudin, 2012: 61). Menurut Abdul Halim (2008: 4-5) dalam Rudy Badrudin (2012), belanja modal adalah investasi yang berupa pengadaan atau pembelian aset yang bermanfaat lebih dari 12 (dua belas) bulan dan aset tersebut digunakan dalam kegiatan pemerintahan yang bermanfaat secara ekonomis, sosial, dan manfaat lainnya sehingga dapat meningkatkan kemampuan pemerintah dalam melayani masyarakat. Dengan demikian, belanja modal bermanfaat untuk meningkatkan kesejahteraan masyarakat. Aset tetap merupakan prasyarat utama dalam memberikan pelayanan publik oleh pemerintah daerah. Untuk menambah asset tetap, pemerintah daerah mengalokasikan dalam bentuk belanja modal dalam APBD. Alokasi belanja modal ini didasarkan pada kebutuhan daerah akan sarana dan prasarana, baik untuk kelancaran pelaksanaan tugas pemerintahan maupun untuk fasilitas publik. Biasanya setiap tahun diadakan pengadaan aset tetap oleh pemerintah, sesuai dengan prioritas anggaran dan pelayanan publik yang memberikan dampak jangka panjang secara finansial. Menurut Abdul Halim (2007: 113-114) dalam Rudy Badrudin (2012) 


\section{Pertumbuhan Ekonomi}

Secara umum, pertumbuhan ekonomi didefenisikan sebagai peningkatan kemampuan dari suatu perekonomian dalam memproduksi barang-barang dan jasa-jasa. Pertumbuhan ekonomi adalah salah satu indikator yang amat penting dalam melakukan analisis tentang pembangunan ekonomi yang terjadi pada suatu negara. Pertumbuhan ekonomi menunjukkan sejauh mana aktivitas perekomian akan menghasilkan tambahan pendapatan masyarakat pada suatu periode tertentu. Karena pada dasarnya aktivitas perekonomian adalah suatu proses penggunaan faktor-faktor produksi untuk menghasilkan output, maka proses ini pada gilirannya akan menghasilkan suatu aliran balas jasa terhadap faktor produksi yang dimiliki oleh masyarakat. Dengan adanya pertumbuhan ekonomi maka diharapkan pendapatan masyarakat sebagai pemilik faktor produksi juga akan meningkat.

Dengan perkataan lain bahwa pertumbuhan ekonomi lebih menunjuk kepada perubahan yang bersifat kuantitatif (quantitative change) dan biasanya diukur dengan menggunakan data Produk Domestik Bruto (PDB) atau pendapatan atau nilai akhir pasar (total market value) dari barang-barang akhir dan jasa-jasa (final goods and services) yang dihasilkan dari suatu perekonomian selama kurun waktu tertentu (biasanya satu tahun).

Perlu diketahui bahwa pertumbuhan ekonomi berbeda dengan pembangunan ekonomi, kedua istilah ini mempunyai arti yang sedikit berbeda. Kedua-duanya memang menerangkan mengenai perkembangan ekonomi yang berlaku. Tetapi biasanya, istilah ini digunakan dalam konteks yang berbeda. Pertumbuhan selalu digunakan sebagai suatu ungkapan umum yang menggambarkan tingkat perkembangan sesuatu negara, yang diukur melalui persentasi pertambahan pendapatan nasional riil. Istilah pembangunan ekonomi biasanya dikaitkan dengan perkembangan ekonomi di negara-negara berkembang. Dengan perkataan lain, dalam mengartikan istilah pembangunan ekonomi, ahli ekonomi bukan saja tertarik kepada masalah perkembangan pendapatan nasional riil, tetapi juga kepada modernisasi kegiatan ekonomi, misalnya kepada usaha merombak sektor pertanian yang tradisional, masalah mempercepat pertumbuhan ekonomi dan masalah perataan pembagian pendapatan (Sukirno, 2006:423)

\section{METODE PENELITIAN}

\section{Model Jalur}

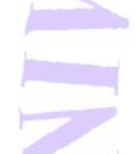

Model jalur ialah suatu diagram yang menghubungkan jaringan hubungan beberapa variabel yang diletakan secara berurutan yang akan dikaji dalam riset. istilah konvensionalnya ialah hubungan antara variable bebas, perantara dan tergantung. Pola hubungan dalam path analysis ditunjukan dengan menggunakan anak panah. Anak panah-anak panah tunggal menujukan hubungan sebab-akibat antara variabel-variabel bebas X1 dan X2 yang dalam path analysis kemudian disebut dengan variabel Exogenus dan/ atau perantara X3 dengan satu variabel tergantung atau lebih yang dalam path analysis disebut sebagai variabel Endogenus Y.

\section{Variabel Exogenous}

Variabel-variabel Exogenous dalam suatu model jalur ialah semua variabel yang tidak ada penyebabpenyebab eskplisitnya atau pada bagian kesalahan dalam pengukuran variable ini berfungsi sebagai variabel bebas / penyebab terhadap variabel urutan sesudahnya yang disebut Endogenus.

\section{Variabel Endogenus}

Variabel endogenus ialah variabel yang mempunyai anak-anak panah yang menuju kearah variabel-variabel tersebut ( variabel X3 untuk sub struktur X1 dan variabel Y untuk sub struktur X2). Variabel yang termasuk didalamnya ialah mencakup semua variabel perantara dan tergantung. Variabel perantara endogenus mempunyai anak panah yang menuju ke arahnya dan dari arah variabel tersebut dalam suatu model diagram jalur. Sedangkan variabel tergantung hanya mempunyai anak panah yang menuju kearahnya.

\section{Pengertian dan Tujuan Menggunakan Path Analysis}

"Path analysis merupakan perluasan dari regresi linier berganda, dan yang memungkinkan analisis modelmodel yang lebih kompleks" (Streiner, 2005). "path analysis ialah suatu teknik untuk menganalisis hubungan sebab akibat yang terjadi pada regresi berganda jika variabel bebasnya mempengaruhi variabel tergsntung 
tidak hanya secara langsung” (Robert D. Retherford 1993). Sedangkan menurut Paul Webley (1997) "path analysis merupakan pengembangan langsung bentuk regresi berganda dengan tujuan untuk memberikam estimasi tingkat kepentingan ( magnitude) dan signifikasi (significance) hhubungan sebab akibat hipotetikal dalam seperangkat variabel". David Garson (2003) dari North California State University mengidentifikasikan model analysis path sebagai " perluasan regresi yang digunakan untuk menguji keselarasan matriks kolerasi dengan dua atau lebih model hubungan sebab akibat yang dibandingkan oleh peneliti".

Modelnya digambarkan dalam bentuk lingkaran dan panah dimana anak panah yang tunggal menunjukan sebagai penyebab. Regresi dikenakan pada masing-masing variabel dalam suatu model sebagai penyebab. Pembobotan regresi diprediksikan dalm suatu model yang dibandingkan dengan matriks kolerasi yang diobservasi untuk semua variabel dan dilakukan juga perhitungan uji keselarasan statistik.

Menurut penulis path analysis merupakan teknik analisis yang digunakan untuk menganalisis hubungan sebab akibat yang inheren antara variabel yang disusun berdasarkan urutan temporer dengan menggunakan koefisien jalur sebagai besaran nilai dalam menentukan besarnya pengaruh variabel independen exogenous terhadap variabel dipenden endogenous( Jonathan Sarwono, 2011)

Dari definisi diatas dapat sismpulkann bahwa sebenarnya path analysis dapat dikatakan sebagai kepanjangan dari analisis regresi berganda, meski didasarkan sejarah terdapat perbedaan dasar antara path analysis yang bersifat independen terhadap prosedur statistic dalam menentukan hubungan sebab akibat sedang regresi linier memang merupakan prosedur stastik yang digunakan untuk menganalisis hubungan sebab akibat antara variabel yang dikaji.

\section{Tujuan Path Analysis}

Tujuan menggunajkan path analysis diantaranya ialah untuk:

1. Melihat hubangan antara variabel dengan didasarkan pada model apriori

2. Menerangkan mengapa variabel-variabel berkolerasi dengan menggunakan suatu model yang berurutan secara temporer.

3. Menggambar dan menguji suatu model matematis dengan menggunakan persamaan yang mendasarinya.

4. Mengidentifikasi jalur penyebab suatu variabel tertentu terhadap vaariabel-variabel lain yang dipengaruhinya.

5. Menghitung besarnya pengaruh satu variabel independen exogenous atau lebih terhadap variabel dependen endogenous lainya.

\section{HASIL PENELITIAN DAN PEMBAHASAN}

\section{Hasil Penelitian}

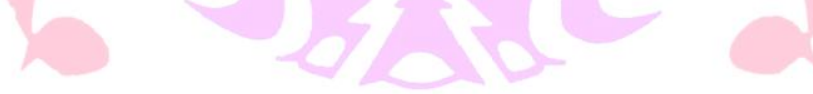

Dari hasil penelitian yang di dapat dalam Pengaruh Pendapatan pajak, pendapatan retribusi terhadap belanja modal dan dampaknya terhadap pertumbuhan ekonomi adalah sebagai berikut :

\section{Variabel penelitian}

$\mathrm{X}_{1}$ = Pendapatan Pajak

$\mathrm{X}_{2}=$ Pendapatan Retribusi

$\mathrm{X}_{3}=$ Belanja Modal

$\mathrm{Y}=$ Pertumbuhan Ekonomi

\section{Diagram Jalur penelitian}

Dimana dibawah ini merupakan Diagram penelitian yang di lakukan oleh peneliti dalam mencari Pengaruh yang ditimbulkan oleh Variabel Dependen Exogenus terhadap Variabel Independen Exogenus. 


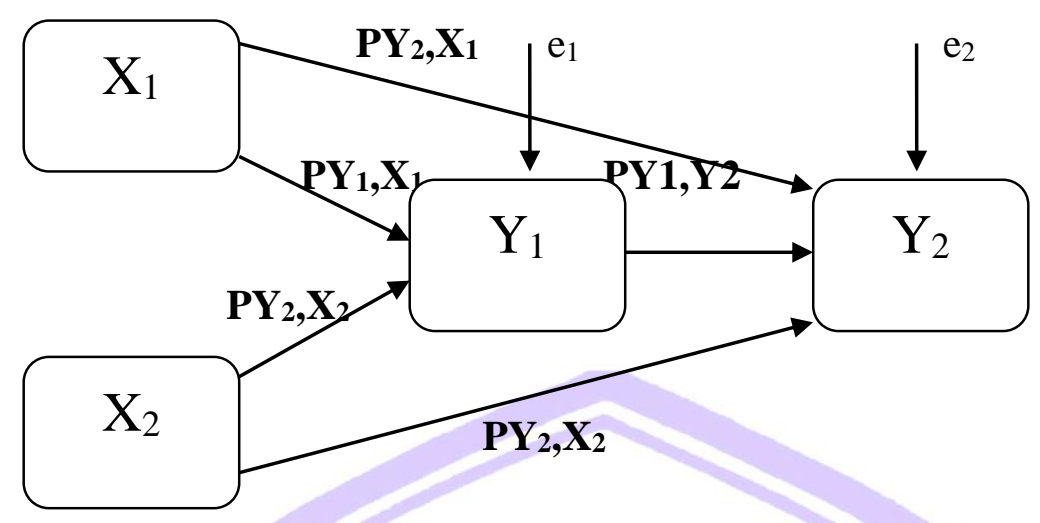

Gambar 1 Diagram Jalur Pengaruh pendapatan pajak, pendapatan retribusi terhadap belanja modal dan dampaknya terhadap pertumbuhan ekonomi

Diagram jalur di atas menunjukan dimana

$\mathrm{X}_{1}$ sebagai Variabel Independen Exogenus Pendapatan Pajak

$\mathrm{X}_{2}$ sebagai Variabel Independen Exogenus Pendapatan Retribusi

$\mathrm{Y}_{1}$ sebagai Variabel Dependen Endogenus Belanja Modal

$\mathrm{Y}_{2}$ sebagai Variabel Endogenus Pertumbuhan Ekonomi

Diagram jalur diatas mempunyai dau persamaan struktural. Persamaan strukturalnya dapat dilihat seperti dibawah ini

$$
\begin{gathered}
\mathrm{Y}_{1}=\mathrm{PY} 1, \mathrm{X} 1+\mathrm{PY} 1, \mathrm{X} 2+\mathrm{e}_{1} \\
\mathrm{Y}_{2}=\mathrm{PY}_{2}, \mathrm{X}_{1}+\mathrm{PY}_{2}, \mathrm{X}_{2}+\mathrm{PY}_{2}, \mathrm{Y}_{1}+\mathrm{e}_{2}
\end{gathered}
$$

\section{Pengujian Asumsi klasik}

\section{Perhitungan Sub Struktur I}

Tabel 1 Multikolerasi Coefficients ${ }^{a}$

\begin{tabular}{|ll|l|l|}
\hline Model & & $\begin{array}{l}\text { Collinearity } \\
\text { Statistics }\end{array}$ & $\begin{array}{l}\text { Collinearity } \\
\text { Statistics }\end{array}$ \\
\cline { 3 - 4 } & VIF & Tolerance \\
\hline \multirow{3}{*}{1} & & \\
& (Constant) & 5.919 & 169 \\
& Pajak & 5.919 & 169 \\
\hline
\end{tabular}

a. Dependent Variable: Modal

Sumber Data : pengolahan data 2016

Dilihat dari tabel 1 Coefficients nilai VIF pada Output menunjukkan keberadaan multikolinearitas.

Bila VIF $<10,00$ maka tidak terjadi gejala Multikolerasi

Bila VIF > 10,00 maka terjadi gejala Multikolerasi

Dengan Hasil :

Nilai Tolerance :

X1 Dana Alokasi Umum

$$
=0,169
$$

X2 Belanja Langsung

$=0,169$

Nilai VIF

X1 Dana Alokasi Umum

$=5,919$

X2 Belanja Langsung

$=5,919$ 


\section{Uji Heterokoledasitas}

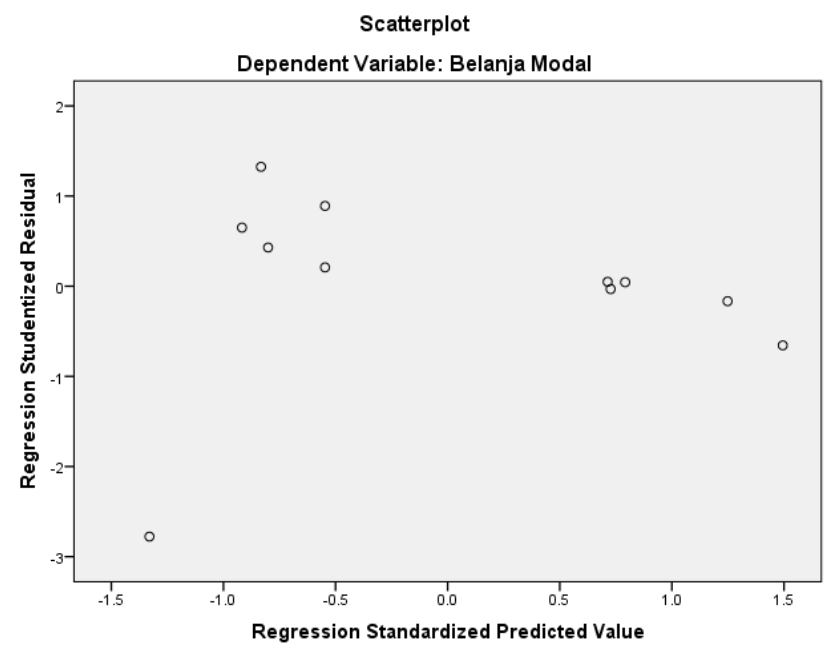

Gambar 2 Diagram scaterplot

Dari diagram diatas tersebut terlihat bahwa penyebaran residual tidak teratur. Hal tersebut terlihat pada plot yang terpancar dan tidak membentuk pola tertentu. Dengan hasil demikian, kesimpulan yang biasa diambil adalah bahwa tidak terjadi gejala homokedastisitas atau persamaan regresi memenuhi asumsi heterokedatisitas.

Uji Autokorelasi

Tabel 2 Model Summary(b)

\begin{tabular}{|l|l|l|l|}
\hline \multirow{2}{*}{ Model } & \multicolumn{2}{|l|}{ Change Statistics } & \\
\cline { 2 - 3 } & df2 & Sig. F Change & \\
\hline 1 & $8 \mathrm{a}$ & .044 & .923 \\
\hline
\end{tabular}

a. Predictors: (Constant), Pajak, Retribusi

b. Dependent Variable: Belanja Modal

Sumber Data : pengolahan data 2016

Pada analisis regresi telihat bahwa nilai DW 0.923 dan nilai DL 0.594 , dan DU 1.928 . DL < DW < DU yakni 0.594 DL, 0.923 DW, 0.594 DU. berada pada antara DL dan DU dan berada pada titik keraguraguan. Maka dapat disimpulkan bahwa terdapat gejala autokorelasi yang lemah. Hasil Perhitungan (output) untuk substruktur satu dengan menggunakan SPSS 20,0 adalah sebagai berikut :

\begin{tabular}{|ll|l|l|l|}
\hline \multicolumn{3}{|c|}{ Tabel 3 Correlations } \\
\hline \multirow{3}{*}{ Pearson Correlation } & Belanja Modal & Retribusi & Pajak \\
& Belanja Modal & 1.000 & .633 & .731 \\
& Retribusi & .633 & 1.000 & .912 \\
& Pajak & .731 & .912 & 1.000 \\
& Belanja Modal &. & .018 & .005 \\
& Retribusi & .018 &. & .000 \\
& Pajak & .005 & .000 & .11 \\
& Belanja Modal & 11 & 11 & 11 \\
& Retribusi & 11 & 11 & 11 \\
\hline
\end{tabular}

Sumber Data : pengolahan data 2016 
Dari tabel 3 Correlations diatas menunjukan bahwa Koefisien Korelasi Pearson Pendapatan pajak dengan Belanja Modal adalah 0,731 dengan nilai sig 0,005, koefisien korelasi diantara Pendapatan retribusi dan belanja modal adalah 0.633 dengan nilai sig 0,018. Dengan demikian dilihat dalam kondisi tersebut dimana nilai signifikan $<0,05$. Maka kesimpulan yang diambil adalah $\mathrm{H} 0$ di tolak, dan $\mathrm{H} 1$ di terima. Yang berarti Koefisien Korelasi adalah signifikan secara statistic Dalam melihat pengaruh Variabel Independen Exogenus Pendapatan Pajak dan Retribusi secara gabungan terhadap variabel Dependen Endogenus dapat Belanja Modal dilihat dari Tabel 4.5 Model Summary dibawah ini pada nilai $R$ square. Besarnya $R$ square $\left(\mathrm{R}^{2}\right)$ pada tabel dibawah ini adalah 0,541. Angka tersebut mempumpunyai makna Besarnya pengaruh Variabel indeependen exogenous pendapatan pajak dan retribusi terhadap variabel dependen endogenus belanja modal secara gabungan. Dalam menghitung Koefisien Determinasi (KD) dapat diketahui dengan rumus, KD $=\mathrm{R} 2 \mathrm{x}$ $100 \%, \mathrm{KD}=0,541 \times 100 \%, \mathrm{KD}=54,1 \%$.

Besarnya pengaruh Variabel Independen Exogenous Pendapatan pajak dan retribusi terhadap Variabel Dependen Endogenus Belanja Modal secara gabungan adalah 54,1\%. Dan pengaruh di luar model dapat di hitung dengan rumus : $\mathrm{e}=1-\mathrm{R}^{2}, \mathrm{e}=1-0,541, \mathrm{e}=0,459 \times 100 \%, \mathrm{e}=45,9 \%$.

Yang berarti $45,9 \%$ berarti besarnya faktor lain yang mempengaruhi diluar model yang di teliti. Artinya besarnya pengaruh variabel independen eksogenus pendapatan pajak dan retribusi terhadap variabel dependen endogenus Belanja modal adalah sebesar 54,1\%, sedangkan pengaruh sebesar $45,9 \%$ disebabkan oleh variabel di luar model yang di teliti.

Tabel 4 Model Summary(b)

\begin{tabular}{|l|l|l|l|l|l|l|l|}
\hline Model & $\mathrm{R}$ & R Square & $\begin{array}{l}\text { Adjusted R } \\
\text { Square }\end{array}$ & $\begin{array}{l}\text { Std. Error of } \\
\text { the Estimate }\end{array}$ & & & \multicolumn{2}{|l|}{$\begin{array}{l}\text { Change Statistics } \\
\text { R Square } \\
\text { Change }\end{array}$} & F Change & df1 \\
\hline 1 & & & & & & & \\
\hline
\end{tabular}

Pengaruh variabel independen exogenous Pendapatan Pajak Dan Retribusi secara parsial terhadap variabel dependen endogenus Belanja Modal.

Besarnya pengaruh variabel independen exogenous Pendapatan Pajak dan Retribusi terhadap variabel dependen endogenus Belanja Modal secara Parsial dapat dilihat dari nilai Beta atau Standardized Coefficients .dan untuk pengujian digunakan nilai t. Dapat dilihat pada Tabel 5 dibawah ini

Tabel 5 Coefficients(a)

\begin{tabular}{|c|c|c|c|c|c|c|}
\hline \multirow{2}{*}{\multicolumn{2}{|c|}{ Model }} & \multicolumn{2}{|c|}{$\begin{array}{l}\text { Unstandardized } \\
\text { Coefficients }\end{array}$} & \multirow{2}{*}{\begin{tabular}{|l|}
$\begin{array}{l}\text { Standardized } \\
\text { Coefficients }\end{array}$ \\
Beta \\
\end{tabular}} & \multirow[t]{2}{*}{$\mathrm{t}$} & \multirow[t]{2}{*}{ Sig. } \\
\hline & & B & Std. Error & & & \\
\hline \multirow{3}{*}{1} & (Constant) & 4.255 & 4.945 & & .861 & 415 \\
\hline & Retribusi & -.334 & .981 & -.198 & -.340 & .743 \\
\hline & Pajak & .947 & .605 & .912 & 1.565 & 156 \\
\hline
\end{tabular}

Sumber Data : pengolahan data 2016

\section{Pengaruh Variabel Independen Exogenous Pendapatan Pajak terhadap Variabel Dependen Endogenus Belanja Modal.}

Untuk melihat apakah ada Pengaruh Linier Variabel Independen Exogenus Pendapatan Pajak terhadap Variabel Dependen Endogenus Belanja Modal. Dapat dilihat pada tabel 5 Coefficients(a)

Menentukan besarnya taraf Signifikan sebesar 0,05 dan Degree of Freedom DF $=\mathrm{n}-(\mathrm{K}+1)$ atau $\mathrm{DF}=11-$ $(2+1)=8$. Dari ketentuan tersebut diperoleh $\mathrm{t}$ tabel sebesar 1,859 (untuk uji dua arah). Dalam perhitungan SPSS yang tertera pada tabel Coefficients di atas dimana tabel $t$ adalah untuk menunjukan bahwa adanya Pengaruh linier antara Variabel Independen Exogenus Pendapatan pajak terhadap Variabel Dependen Endogenus Belanja Modal ialah 1,565. Hasil dari perhitungan dengan SPSS menunjukan angka t hitung sebesar 1,565 < t tabel sebesar 1,859. Dengan demikian keputusanya ialah H0 diterima, dan H1 ditolak. Artinya tidak ada hubungan linier antara Variabel Independen Exogenus Pendapatan Pajak terhadap Variabel Dependen Endogenus Belanja Modal. Maka Variabel Independen Exogenus Pendapatan Pajak tidak 
berpengaruh terhadap Variabel Dependen Endogenus Belanja Modal. Besarnya Koefisien Beta pada tabel 4.6 di atas (dalam kolom Standardized Coefficient Beta) sebesar 0,912 atau jika dibuat persen menjadi sebesar 91,2 \% menunjukan bahwa pengaruh sebesar ini tidak signifikan karena nilai signifikansi / probabilitas hasil yang tertera pada kolom Sig 0,156 > 0,05.

\section{Pengaruh antara variabel Independen Exogenus Pendapatan Retribusi terhadap Variabel Dependen Endogenus Belanja Modal.}

Untuk melihat apakah ada hubungan Linier Variabel Independen Exogenus Pendapatan retribusi terhadap Variabel Dependen Endogenus Belanja Modal.

Nilai t hasil perhitungan dengan menggunakan SPSS yang tertera pada kolom t pada tabel Coefficients diatas untuk menunjukan adanya hubungan Linier antara Variabel Independen Exogenus Pendapatan Retribusi dengan Variabel Dependen Endogenus Belanja Modal adalah -0,340. Menentukan besarnya taraf Signifikan sebesar 0,05 dan Degree of Freedom DF $=\mathrm{n}-(\mathrm{K}+1)$ atau $11-(2+1)=8$. Dari ketentuan tersebut diperoleh $\mathrm{t}$ tabel sebesar 1,859 (untuk uji dua arah).

Hasil dari perhitungan dengan SPSS menunjukan angka $\mathrm{t}$ hitung sebesar $-0,340<\mathrm{t}$ tabel sebesar 1,859 . Dengan demikian keputusanya ialah $\mathrm{H} 0$ diterima dan $\mathrm{H} 1$ ditolak. Artinya tidak ada pengaruh linier antara Variabel Independen Exogenus Pendapatan Retribusi terhadap Variabel Dependen Endogenus Belanja Modal. Maka Variabel Independen Exogenus Pendapatan Retribusi tidak berpengaruh terhadap Variabel Dependen Endogenus Belanja Modal. Besarnya pengaruh Variabel Independen Exogenus Pendapatan Retribusi terhadap Variabel Dependen Endogenus Belanja Modal diketahui dari nilai Koefisien Beta (dalam kolom Standardized Coefficients Beta) ialah --0,198 atau jika dibuat persen 19,8\% pengaruh sebesar ini tidak Signifikan karena nilai signifikansi / probabilitas hasil yang tertera pada kolom Sig 0,743>0,05.

\section{Melihat Kelayakan Model Regresi}

untuk mengetahui model regresi yang telah dibuat sudah benar adalah dengan menggunakan pengujian dengan menggunakan pengujian dengan dua cara, yaitu Pertama menggunakan nilai $\mathrm{F}$ pada tabel keluaran ANOVA, dan Kedua dengan cara menggunakan nilai Probabilitas / nilai Sig pada tabel keluaran ANOVA.

Tabel 6 ANOVA(b)

\begin{tabular}{|ll|l|l|l|l|l|}
\hline Model & & Sum of Squares & df & Mean Square & F & Sig. \\
\hline \multirow{2}{*}{1} & Regression & .380 & 3 & .127 & 39.144 & $.000^{\mathrm{b}}$ \\
& Residual & .023 & 7 & .003 & & \\
& Total & .402 & 10 & & & \\
\hline
\end{tabular}

a. Dependent Variable: PDRB

b. Predictors: (Constant), Pajak, Belanja Modal, Retribusi

Sumber Data : pengolahan data 2016

Nilai F hitung dari keluaran SPSS ialah 4,722, Menghitung nilai F tabel dengan Ketentuan besar nilai taraf Signifikansi sebesar 0,05 dan Nilai Degree Of Freedom dengan ketentuan Numerator / Vektor 1 : Jumlah Variabel -1 atau 3-1=2, dan dumerator / Vektor 2: jumlah kasus-jumlah variabel atau $9-3=6$. Dengan ketentuan terdebut diperoleh angka $F$ tabel sebesar 5,14 . Hasil perhitungan dengan SPSS didapatkan angka $\mathrm{F}$ hitung sebesar 14,722 > F tabel sebesar 5,14. Dengan demikian H0 ditolak, dan H1 diterima. Artinya ada hubungan linier antara Variabel Independen Pendapatan Pajak dan Retribusi dengan Variabel Dependen Endogenus Belanja Modal. Dengan nilai Sig 0,004 Kesimpulan adalah model regresi di atas sudah layak dan benar. 
Perhitungan Sub Struktur II

Tabel 7 Coefficients (VIF) (a)

\begin{tabular}{|ll|l|}
\hline Model & Collinearity Statistics \\
\cline { 3 - 3 } & & VIF \\
\hline \multirow{3}{*}{1} & (Constant) & \\
& Belanja Modal & 2.180 \\
& Retribusi & 6.004 \\
& Pajak & 7.732 \\
\hline
\end{tabular}

a Dependent Variable: Pertumbuhan Ekonomi (PDRB)

Sumber Data : pengolahan data 2016

dilihat dari Tabel Coefficients ${ }^{\mathrm{a}}$ nilai VIF pada out-put menunjukan keberaadaan Multikolinearitas tidak signifikan, artinya tidak ada indikasi Multikolinearitas dalam model. Ini ditunjukan dengan nilai VIF berturut-turut untuk X1 Pajak, X2 Retribusi, dan X3 Belanja Modal. Adalah lebih kecil dari 10,0 .

Pengaruh Variabel Independen Eksogenus Pendapatan Pajak Dan Retribusi Terhadap Belanja Modal Secara Gabungan Terhadap Variabel Dependen Endogenus Pertumbuhan Ekonomi.

Untuk melihat hubungan pengaruh variabel Independen Exogenus Pendapatan Pajak dan Retribusi terhadap Belanja Modal dan Variabel Endogenus Kemiskinan secara gabungan dapat dilihat pada Tabel Model Summary, dalam angka R square di bawah ini.

Tabel 8 Model Summary R-square(b)

\begin{tabular}{|c|c|c|c|c|c|c|c|}
\hline \multirow[t]{2}{*}{ Model } & \multirow[t]{2}{*}{$\mathrm{R}$} & \multirow[t]{2}{*}{ R Square } & \multirow{2}{*}{$\begin{array}{l}\text { Adjusted R } \\
\text { Square }\end{array}$} & \multirow{2}{*}{$\begin{array}{l}\text { Std. Error of } \\
\text { the Estimate }\end{array}$} & \multicolumn{3}{|c|}{ Change Statistics } \\
\hline & & & & & $\begin{array}{l}\text { R Square } \\
\text { Change }\end{array}$ & F Change & df1 \\
\hline 1 & $.971^{\mathrm{a}}$ & .944 & .920 & .05686 & .944 & 39.144 & 3 \\
\hline
\end{tabular}

a Predictors: (Constant), Pajak, Retribusi, Belanja Modal

b Dependent Variable: Pertumbuhan Ekonomi (PDRB)

Sumber Data : pengolahan data 2016

Besarnya pengaruh Rsquare $\left(\mathrm{R}^{2}\right)$ pada tabel diatas adalah 0,944 . Angka tersebut mempunyai makna besarnya pengaruh variabel independen exogenous Pendapatan Pajak, Pendapatan Retribusi dan Belanja Modal terhadap Pertumbuhan Ekonomi secara gabungan. dalam menghitung Koefisien Determinasi (KD) dapat di hitung dengan Rumus sebagai berikut. $\mathrm{KD}=\mathrm{R} 2 \times 100 \%, \mathrm{KD}=0,944 \times 100 \%, \mathrm{KD}=94,4 \%$. Angka 94,4\% mempunyai makna besarnya pengaruh Variabel Independen Exogenus Pendapatan Pajak, Pendapatan Retribusi dan Belanja Modal terhadap Pertumbuhan Ekonomi (PDRB) secara gabungan. sedangkan sisanya dapat dihitung dengan menggunakan rumus sebagai berikut :e $=1-\mathrm{R} 2, \mathbf{e}=1-0,944, \mathbf{e}=0,056, \mathbf{e}=0,056 \mathrm{x}$ $100 \%, \mathbf{e}=5,6 \%$

Variabelitas Kemiskinan yang dapat diterangkan dengan menggunakan Variabel Independen Exogenus Pendapatan Pajak, pendapatan Retribusi dan Belanja Modal terhadap Pertumbuhan Ekonomi (PDRB) adalah sebesar 94,4\% , sedangkan besarnya pengaruh dari Variabel diluar model adalah sebesar 5,6\%.

Pengaruh Variabel Independen Exogenus Pendapatan Pajak, Retribusi dan Belanja Modal secara Parsial terhadap Variabel Dependen Pertumbuhan Ekonomi (PDRB).

Besarnya pengaruh Variabel Independen Exogenus Pendapatan Pajak, Pendapatan Retribusi dan Belanja Modal terhadap Pertumbuhan ekonomi secara Parsial. 
Tabel 9 Coefficients(T Count) (a)

\begin{tabular}{|ll|l|l|l|l|l|}
\hline \multirow{2}{*}{ Model } & \multicolumn{2}{|l|}{ Unstandardized Coefficients } & $\begin{array}{l}\text { Standardized } \\
\text { Coefficients }\end{array}$ & \multirow{2}{*}{ Sig. } \\
\cline { 2 - 5 } & & B & Std. Error & Beta & & \\
\hline \multirow{3}{*}{1} & (Constant) & .197 & 1.065 & & .185 & .859 \\
& Belanja Modal & .103 & .073 & .187 & 1.415 & .200 \\
& Retribusi & .145 & .204 & .156 & .712 & .500 \\
& Pajak & .390 & .142 & .682 & 2.738 & .029 \\
\hline
\end{tabular}

a Dependent Variable: Pertumbuhan Ekonomi (PDRB)

Sumber Data : pengolahan data 2016

Pengaruh antara variabel Independen Exogenus Dana Alokasi Umum (DAU) dengan Variabel Dependen Endogenus Kemiskinan.

Dari hasil perhitungan dengan menggunakan SPSS yang tertera pada kolom $\mathrm{t}$ pada tabel Coefficients diatas untuk menunjukan adanya hubungan linier antara Variabel Independen Exogenus Pendapatan Pajak dengan Variabel Dependen Endogenus Kemiskinan ialah sebesar 2.738 Menentukan besarnya taraf signifikansi sebesar 0,05 dan Degree of Freedom DF dengan ketentuan: $\mathrm{DF}=\mathrm{n}-(\mathrm{K}+1)$ atau $\mathrm{DF}=11-(3+1)=7$ dari ketentuan tersebut diperoleh angka t tabel untuk uji dua sisi adalah sebesar 1,894. Hasil dari perhitungan dengan menggunakan SPSS menunjukan angka t hitung sebesar $2.738>1,894$, dengan demikian keputusanya adalah H0 ditolak, dan H1 diterima. Artinya ada hubungan linier antara Variabel Independen Exogenus Pendapatan Pajak terhadap Variabel Dependen Endogenus Pertumbuhan Ekonomi. Nilai koefisien Beta ( dalam kolom Standardized Coefficient Beta) sebesar 0,682 atau jika dibuat dalam persen menjadi 68,2 $\%$ menunjukan bahwa pengaruh sebesar ini tidak signifikan karena nilai signifikansi / probabilitas hasil perhitungan yang tertera dalam kolom sig sebesar $0,029>0,05$.

Pengaruh antara Variabel Independen Exsogenus Belanja Langsung terhadap Variabel Independen Endogenus Kemiskinan.

Dari hasil perhitungan dengan menggunakan SPSS yang terterah pada kolom t pada tabel Coefficients di atas untuk menunjukan hubungan linier antara Variabel Independen Exogenus Pendapatan Retribusi terhadap variabel Dependen Pertumbuhan Ekonomi adalah 0.712 Menentukan taraf signifikansi sebesar 0,05 dan Degree Of Freedom $(\mathrm{DF}) . \mathrm{DF}=\mathrm{n}-(\mathrm{K}+1)$ atau $11-(3+1)=7$ dari ketentuan tersebut diperoleh angka t tabel sebesar 1.894

Hasil perhitungan dengan menggunakan SPSS menunjukan angka t hitung 0,712 < t tabel sebesar 1.894. Dengan demikian keputusanya adalah $\mathrm{H} 1$ ditolak dan $\mathrm{H} 0$ diterima, artinya tidak ada hubungan linier antara variabel Independen Exogenus Pendapatan Retribusi dengan Variabel Dependen Endogenus Pertumbuhan Ekonomi. Maka variabel Exogenus Independen Endogenus Pendapatan Retribusi tidak mempengaruhi Variabel Dependen Endogenus Pertumbuhan Ekonomi. Nilai koefisien Beta (dalam kolom Standardized Coefficient Beta) sebesar 0,156 atau jika dibuat dalam persen sebesar 15,6 \% menujukan bahwa pengaruh sebesar ini tidak signifikan karena nilai signifikansi / probabilitas hasil perhitungan yang tertera dalam kolom Sig sebesar sebesar $0,500>0,05$

Pengaruh antara Variabel Independen Exsogenus Pertumbuhan Belanja Modal terhadap Variabel Independen Endogenus Pertumbuhan Ekonomi.

Dari hasil perhitungan dengan menggunakan SPSS yang tertera pada kolom t pada tabel Coefficients di atas untuk menunjukan hubungan linier antara Variabel Independen Exogenus Belanja Modal terhadap variabel Dependen Endogenus Pertumbuhan Ekonomi (PDRB) adalah 1,415.

Menentukan taraf signifikansi sebesar 0,05 dan Degree Of Freedom $(\mathrm{DF}) . \mathrm{DF}=\mathrm{n}-(\mathrm{K}+1)$ atau $11-(3+1)=$ 7 dari ketentuan tersebut diperoleh angka t tabel sebesar 1.894

Hasil perhitungan dengan menggunakan SPSS menunjukan angka $t$ hitung sebesar 1,415 $<\mathrm{t}$ tabel sebesar 1.894. Dengan demikian keputusanya adalah H1 diterima dan H0 ditolak, artinya ada hubungan linier antara variabel Independen Exogenus Belanja Modal dengan Variabel Dependen Endogenus Pertumbuhan Ekonomi (PDRB). Maka variabel Exogenus Independen Endogenus Belanja Modal mempengaruhi Variabel 
Dependen Endogenus Pertumbuhan Ekonomi (PDRB). Nilai koefisien Beta (dalam kolom Standardized Coefficient Beta) sebesar 0.187 atau jika dibuat dalam persen sebesar 18,7\% menujukan bahwa variabel Independen Exogenus Belanja Modal berpengaruh terhadap Variabel Dependen Endogenus Pertumbuhan Ekonomi (PDRB). dengan demikian pengaruh sebesar ini signifikan karena nilai signifikansi / probabilitas hasil perhitungan yang tertera dalam kolom Sig sebesar sebesar 0,00.

\section{Melihat Kelayakan Model Regresi Struktur II}

Untuk mengetahuimodel Regresi yang dibuat telah benar adalah dengan menggunakan Pengujian dua cara yaitu pertama menggunakan nilai F pada tabel keluaran ANOVA, dan kedua dengan cara menggunakan nilai Probabilitas nilai Sig pada tabel keluaran ANOVA.

Tabel 10 ANOVA(F Count) (b)

\begin{tabular}{|c|c|c|c|c|c|c|}
\hline \multicolumn{2}{|l|}{ Model } & Sum of Squares & & Mean Square & $\mathrm{F}$ & Sig. \\
\hline & Regression & .380 & 3 & .127 & 39.144 & $.000^{\mathrm{b}}$ \\
\hline 1 & Residual & .023 & 7 & .003 & & \\
\hline & Total & .402 & 10 & & & \\
\hline
\end{tabular}

a. Dependent Variable: PDRB

b. Predictors: (Constant), Pajak, Belanja Modal, Retribusi

Sumber : Pengolahan Data 2016

Nilai F hitung dari keluaran SPSS ialah 39.144, Menghitung nilai $\mathrm{F}$ tabel dengan ketentuan nilai besar nilai taraf signifikasi sebesar 0,05 dan nilai DF / Vektor 1 : jumlah variabel -1 atau $4-1=3$ dan dumerator Vektor : jumlah kasus - jumlah variabel atau $11-4=7$ dengan ketentuan tersebut diperoleh angka $F$ tabel sebesar 4.35. Hasil perhitungan dengan SPSS didapat angka F hitung sebesar $39.144>F$ tabel sebesar 4.35. Dengan demikian H0 ditolak, dan H1 diterima dengan demikian Ada pengaruh linier antara variabel Independen Exogenus Pendapatan Pajak, Retribusi dan Belanja Modal terhaddap variabel Dependen Endogenus Pertumbuhan Ekonomi (PDRB). Kesimpulan adalah model regresi diatas sudah layak dan benar dengan nilai Sig 0,00 .

\section{Menghitung Pengaruh Langsung DE (Direct Effect)}

Pengaruh Variabel Pajak Terhadap Belanja Modal

$$
\mathrm{X} 1 \mathrm{ke} \mathrm{Y} 1=1.565
$$

Pengaruh Variabel Retribusi Terhadap Belanja Modal

$$
\mathrm{X} 2 \text { ke } \mathrm{Y} 1=-0,340
$$

Pengaruh Variabel Pajak Terhadap Pertumbuhan Ekonomi

$$
\mathrm{X} 1 \mathrm{ke} \mathrm{Y} 2=2.738
$$

Pengaruh Variabel Retribusi Terhadap Pertumbuhan Ekonomi

$$
\mathrm{X} 2 \text { ke } \mathrm{Y} 2=-0,712
$$

Pengaruh Variabel Belanja Modal Terhadap Pertumbuhan Ekonomi

$$
\mathrm{Y} 1 \mathrm{ke} \mathrm{Y} 2=1.415
$$

\section{Pengaruh Tidak Langsung IE (Indirect Effect)}

Pengaruh variabel Pajak terhadap Pertumbuhan Ekonomi Melalui Belanja Modal

$$
\text { PY1X1 x PY2Y1 }=(1.565 \times 1.415)=2.214
$$

Pengaruh variabel Retribusi terhadap Pertumbuhan Ekonomi melalui Belanja Modal

$$
\text { PY1X2 x PY2Y1 }=(-0,340 \times 1.415)=-0.481
$$

\section{Pengaruh Total (Total Effect)}

Pengaruh Variabel Pajak terhadap Pertumbuhan Ekonomi melalui Belanja Modal

$$
\mathrm{PY} 1 \mathrm{X} 1+\mathrm{PY} 2 \mathrm{Y} 1=1.565+1.415=2.980
$$

Pengaruh Variabel Belanja Langsung tehadap Pertumbuhan Ekonomi melalui Kemiskinan

$$
\text { PY1X2 + PY2Y1 }=-0,340+1.415=1.075
$$

Sub Struktur $1: \mathrm{Y} 1: \mathrm{Y} 1 \mathrm{X} 1+\mathrm{Y} 1 \mathrm{X} 2+\mathrm{e}_{1}$ 
Sub Struktur $2: \mathrm{Y} 2: \mathrm{Y} 2 \mathrm{X} 1+\mathrm{Y} 2 \mathrm{X} 2+\mathrm{e}_{2}$

Dimana :

1. Pengaruh variabel Pajak dan Retribusi Terhadap Belanja Modal adalah $0.736^{2}$

2. Pengaruh Variabel Pajak terhadap Belanja Modal secara Langsung adalah $1.565^{2}$

3. Pengaruh Variabel Retribusi secara Langsung terhadap Belanja Modal adalah $-0,340^{2}$

4. Pengaruh Variabel Pajak terhadap Pertumbuhan Ekonomi secara langsung adalah $2.738^{2}$

5. Pengaruh Variabel Retribusi terhadap Pertumbuhan ekonomi secara Langsung adalah $0,712^{2}$

6. Pengaruh Variabel Pajak, Retribusi dan Belanja Modal secara gabungan terhadap Pertumbuhan Ekonomi adalah 0,944²

7. Pengaruh Variabel Belanja Modal terhadap Kemiskinan adalah 1,415

8. Pengaruh Variabel lain diluar Model ini adalah $0,056^{2}$

\section{KESIMPULAN DAN SARAN}

\section{Kesimpulan}

Dari hasil penelitian yang dilakukan mendapatkan hasil bahwa kontribusi maupun pengaruh dari sector pendapatan asli daerah yakni pendapatan pajak, dan pendapatan retribusi masih belum memberikan efek yang signifikan terhadap alokasi belanja modal dari pemerintah kota Manado, hal ini terjadi karena tingkat kemandirian keuangan dari kota Manado sendiri masih kecil, ini berdampak pada pengalokasian anggaran masih bergantung pada sokongan dana dari pemerintah pusat dalam bentuk dana transfer. Dengan terjadinya hal tersebut membuat pengaruh pendapatan asli daerah terhadap alokasi belanja modal yang belum maksimal yang tentunya juga berdampak pada belum maksimalnya pembangunan sector-sektor ekonomi. Sedangkan pengaruh belanja modal terhadap pertumbuhan ekonomi sangat signifikan, hal ini dapat menjadi gambaran bagaimana pertumbuhan ekonomi yang terjadi di kota Manado masih bersumber dan mengandalkan perputaran keuangan yang berasal dari pemerintah, ini juga menunjukan apabila alokasi anggaran pemerintah semakin besar dan mengena pada sasaran maka akan secara continue merangsang perekonomian dan menggenjot roda ekonomi untuk dapat melesat lebih cepat dan jauh, dengan kian berkembangnya perekonomian maka juga akan semakin meningkatkan kemampuan daerah serta pada nantinya akan berujung pada peningkatan masyarakat yang ada di kota Manado sendiri.

\section{Saran}

Berdasarkan hasil penelitian pengaruh pajak dan retribusi terhadap belanja modal dan dampaknya terhadap pertumbuhan ekonomi penulis coba memberikan saran :

1. Pemerintah untuk dapat lebih meningkatkan kemandirianya sehingga dapat lebih menggenjot perekonomian serta pembangunan yang ada di kota Manado.

2. Membuka atau meningkatkan kemampuan serta potensi sumber-sumber ekonomi potensial sehingga nantinya dapat menunjang keuangan daerah sehingga pemerintah dapat merangsang siklus ekonomi yang ada yang nantinya dapat berujung pada peningkatan perekonomian daerah serta meningkatnya perekonomian masyarakat.

\section{DAFTAR PUSTAKA}

Ahmad Yani. (2002). Hubungan Keuangan Antara Pemerintah Pusat dan Daerah di Indonesia. Jakarta: Raja Grafindo Persada.

Abdul Halim.2008. Auditing (dasar-dasar Audit Laporan Keuangan). UUP STIM.

Abdul Halim. (2007). Akuntansi Sektor Publik Akuntansi keuangan daerah, Edisi Revisi, Jakarta, Salemba Empat

BPS Provinsi Sulawesi Utara Profil Manado, Manado dalam angka.2006-2014

Bappeda Kota Manado (tranparansi APBD 2011-2015)

Badrudin, Rudy. 2012. Ekonomika Otonomi Daerah. Yogyakarta: UPP STIM YKPN. 
David Garson, 2003. path analysis. North Carolina State University http:www.mitrariset.com/2009/04/analisi-jalur-path-analysis.html

Halim, Abdul dan Mujib, Ibnu, 2009, Problem desentralisasi dan perimbangan keuangan pemerintahan pusat-daerah peluang dan tantangan dalam pengelolaan sumber daya daerah, Tesis Sekolah Pascasarjanan UGM, Yogyakarta.

Jonathan Sarwono, 2011, Metode Penelitian Kuantitatif \& Kualitatif, (Yogyakarta; Graha Ilmu,

Kevin D. Hoover, Steven M Sheffrin, the American Economics review, vol 82, no.1 (Mar. 1992)

Mahmudi (2010), Manajemen Kinerja Sektor Publik, Edisi Kedua, UPP STIM YKPN, Yogyakarta.

Mahmudi, 2009. Manajemen Keuangan Daerah. Yogyakarta

Mardiasmo. (2002). Otonomi dan Manajemen Keuangan Daerah. Yogyakarta: Andi.

Marihot Pahala Siahan, 2010, Pajak Daerah dan Retribusi Daerah, Edisi Revisi, Jakarta : PT Raja Grafindo Persada

Mahmudi (2010), Manajemen Kinerja Sektor Publik, Edisi Kedua, UPP STIM YKPN, Yogyakarta.

Peraturan menteri dalam negeri Nomor 59 tahun 2007 Tentang Perubahan Atas Peraturan Menteri Dalam

Negeri Nomor 13 Tahun 2006 Tentang Pedoman Pengelolaan Keuangan Daerah

Peraturan Pemerintah Republik Indonesia Nomor 55 Tahun 2005 Tentang Dana Perimbangan

Saragih, Juli Panglima. 2003. Desentralisasi Fiskal dan Keuangan Daerah dalam Otonomi. Cetakan Pertama.

Penerbit Ghalia Indonesia: Jakarta

Sirojuzilam dan Mahalli, K. 2010. Regional. Pembangunan, Perencanaan dan Ekonomi. USU Press. Medan.

Susanto A.B, Ghifari A.B, Susanto A, Suradinata E, Wijanarko H, Supranto J, Karmaji, Oyong R, Nurbaya S dan Martha S, 2010, Reinvensi pembangunan ekonomi daerah, Esensi Erlangga Group, Jakarta.

Sumitro, Rochmad. 1979. Dasar-dasar Hukum Pajak dan PajakPendapatan 1944, cet. IX, Jakarta : Eresco

Sadono Sukirno, 2006, Ekonomi Pembangunan Proses masalahdan Dasar Kebijakan, cetakan ketiga, Penerbit Kencana, Jakarta.

Undang-Undang Republik Indonesia Nomor 32 Tahun 2004 Tentang Pemerintahan Daerah

Undang-undang Republik Indonesia No. 19 Tahun 2001 tentang, Anggaran Pendapatan dan Belanja Negara Tahun 2002. (2002). Jakarta: Eko Jaya.

Undang-undang Republik Indonesia tentang, Perubahan Atas Undang-undang No. 18 Tahun 1997 Tentang

Pajak Daerah dan Retribusi Daerah. (2001). Jakarta: Panca Usaha. 